\title{
Climate Change in the Media: Climate Denial, Ian Plimer, and the Staging of Public Debate
}

Angi Buettner

\section{Introduction}

This article deals with the public and media debates about climate change. It critiques the media framing and staging of these debates, particularly in relation to notions of journalistic objectivity and balance. The logic of the media in covering climate change, and in creating scientific credibility, is discussed on the example of what became known as the Monbiot vs Plimer debate. After George Monbiot (wellknown for his environmental journalism and advocacy) criticised lan Plimer (Australian professor of Mining Geology and quasi-climate scientist) for a book he had published denying climate change, Plimer challenged Monbiot to a public debate on the science of climate change.

"Climate science and climate change denial is a strange area" (Doherty). The more the scientific consensus on anthropogenic climate change consolidates, and the more impacts of climate change become visible (indicating that urgent and drastic action is needed), the louder climate change denial becomes in the debate, "belief" in climate change dwindles, ${ }^{1}$ and a growing number of politicians decides to support environmental policies that do not address climate change. A global deal to tackle climate change in 2010 (at the climate summit in Mexico) is predicted to not eventuate ("Global Warming Deal Unlikely"). There are complex political, financial, and psychological reasons and explanations for this (see for example Dickinson; Hamilton "Social Psychology of Climate Change"; Marshall).

It is useful to consider how these political developments are reflected in the media coverage of climate change issues. In 2009 lan Plimer, an Australian geologist,

\footnotetext{
12009 and 2010 have seen numerous surveys and opinion polls on attitudes to climate change. See for example the survey "Fewer Americans See Solid Evidence of Global Warming" (2009) by the Pew Research Centre for the People \& the Press. Polls that claim a drop in "belief" in climate change seem to receive more media coverage than reports that claim a support of climate change and climate change action. Within the same time frame, there are similar numbers (if not higher) of surveys with results suggesting public concern about climate change worldwide (see for example the report by the World Bank, "Public Attitudes Toward Climate Change: Findings from a MultiCountry Poll"), but this does not become evident from the media coverage. For a source on surveys on public opinion on the environment see WorldPublicOpinion.org.
} 
made a strong impact on public debate over climate change with the publication of his book Heaven and Earth: Global Warming, the Missing Science. 2009 was a crucial year for international environmental governance; December saw the UN Climate Summit in Copenhagen with the goal being to agree on a new global climate treaty to replace the Kyoto Protocol from 1997. In his book, and in his many subsequent media appearances, Plimer declared that "global warming is all a myth", and that the whole of international climate science, politics, and media has united to perform a great climate change con trick. The book sold out almost immediately, stayed on the bestseller lists for months, was taken up by politicians, ${ }^{2}$ and received extensive and prolonged international media attention.

Similarly, the book received numerous reviews by scientists, particularly in Australia, showing the scientific errors and lack of quality of the argument (see for example Ashley; Enting); the author's strong links to the mining industry and polluter cash in Australia also were revealed (Burton). But the book has continued to be picked up enthusiastically by climate change deniers, and by politicians in support of non-action on climate change. Plimer and his book received considerable airing time in the media; some critical, but much of it supportive. The publication of Heaven and Earth put Plimer firmly into the climate change debate. Why did so many media outlets consider Plimer's views to be worthy of public attention? This article uses lan Plimer's uptake in the media in order to discuss some of the logics of the media that come to carry in the climate change debate and influence its quality.

Ian Plimer has considerable cultural capital: as an award-winning scientist, his voice warrants hearing, and he and others in the climate change denial camp use this cultural capital strategically to put their message out into the public sphere through skilful use of the media. However, I will argue that the media aren't merely unwitting victims of cunning deniers who are good at PR and strategic media use, but that the very logic of the media produces rhetoric-driven public debate about climate change. This allows vested interests to control the amplification of voices and to hijack the

2 The book is endorsed, for example, by the 2009 President of the European Union, Vaclav Klaus, a known climate change denier. Or to give just one other example, here is the Australian opposition leader Tony Abbot's uptake of lan Plimer:

I think that in response to the IPCC alarmist - ah in inverted commas - view, there've been quite a lot of other reputable scientific voices. Now not everyone agrees with lan Plimer's position but he is a highly credible scientist and he has written what seems like a very well argued book refuting most of the claims of the climate catastrophists. (Ferguson) 
debate. It also hinders the comprehensive, informative, and incisive media coverage needed in covering climate change and the complexities of its politics and science.

Despite his arguments being thoroughly and convincingly dismantled in the public sphere (see for example Karoly 2009; Manne 2009; Monbiot "Spectator Recycles Climate Rubbish"), Plimer has won the attention of the public mostly by turning himself into a media celebrity, and by strategic lobbying, argument framing, and media use. He fosters an image of the maverick who upholds free debate and fights the silencing of dissent and the censoring of climate change sceptics. He does this loudly and aggressively (see particularly pp. 9-29 and 435-493). At the same time, Plimer works hard on establishing his credibility and expertise. The Australian edition of his book opens with a whole page of "About the author", not merely providing a list but a whole narrative of Plimer's accolades. These include the Eureka Prize: for the promotion of science and science broadcasting (1995), and for A Short History of Planet Earth (2002). ${ }^{3}$

With this claim to credibility and authority, Plimer declares that climate change is a green religion, a communist conspiracy, not based on science, and that there is no scientific consensus. Plimer throws doubts on the science of climate change, mostly by misrepresenting the operation of the IPCC ("It is unrelated to science" p. 20). He discredits environmentalism as a whole, as well as attacking individual advocates. His pet hate is Al Gore, and he uses Gore as a stand-in for the whole of environmentalism and climate science:

Gore founded his own 'green' corporation, Generation Investment Management. He is a board member of a renewable energy company. In many legal jurisdictions, if Gore made speeches about climate change and did not declare his interests, he would be committing a criminal offence. The whole gravy train gained momentum with the establishment of a single-issue group (IPCC), propaganda via Al Gore's fictional Hollywood blockbuster movie An Inconvenient Truth and Mann's infamous 'hockey stick', various partisan economic reports (e.g. Stern, Garnaut) for populist political leaders and an uncritical media looking for horror stories. (442)

3 The Eureka Prizes are for excellence in the fields of scientific research and innovation, science leadership, school science and science journalism and communication. They are funded by partnerships between the Australian Museum and sponsors and supporters (“Australian Museum Eureka Prizes"). 
This is just one example of Plimer's aggressive style and all-out attack. Not declaring one's interests when making speeches about climate change is an offence Plimer is guilty of himself (see later in the article). Later in the book he discredits Nicholas Stern's (2007) report on the economics of climate change:

The first page of Stern's science has basic errors of fact, exaggeration, misquotation, opinion, science created ex nihilo and fulfilment of preordained dogma. (478)

Plimer does not even attempt to provide any evidence for these claims. He is comfortable simply stating what he considers to be the facts.

His rhetorical coup, however, is to make a simple story out of climate change, an extremely complex issue. "There is no problem with global warming" (25), it's that simple. Plimer substantiates this claim by saying that:

We humans normally seek a warmer climate for our holidays. Maybe warming is good for us? (468)

He further banalises the issues by having a joke about how climate scientists "fear warmth" (461). More importantly, however, Plimer turns climate change into part of planet Earth's geological history. He in effect naturalises, or, rather, re-naturalises what is anthropogenic climate change into a natural phenomenon, so that we don't have to worry about the environmental impacts of our industries and actions. According to Plimer, the climate change of the past century was not driven by human action, but by planetary and galactic factors, as has always been the case during the history of our planet. There has been no warming since 1998, and CO2 emissions don't matter (see for example 109). Plimer's evaluation of decades of international climate science is: "If we humans, in a fit of ego, think we can change these normal planetary processes, then we need stronger medication" (11). One of the scientists who reviewed Plimer's book summarises the quality of its content and argumentation:

The arguments that Plimer advances in the 503 pages and 2311 footnotes in Heaven and Earth [sic] are nonsense. The book is largely a collection of contrarian ideas and conspiracy theories that are rife in the blogosphere. The writing is rambling and repetitive; the arguments flawed and illogical. [...] It is not 'merely' atmospheric scientists that would have to be wrong for Plimer to be right. It would require a rewriting 
of biology, geology, physics, oceanography, astronomy and statistics.

(Ashley)

None of Plimer's claims are new; they are familiar messages by climate change deniers. In a book on the role of science in public life, the authors point out not just the organised lobbying campaign against climate change by industries and people connected to them, but also the media savviness of climate change deniers: they are good because they have to be, and they do a full-out attack by all means available, because they know that they need to lobby and that it is about who wins the attention of the public, the media and the politicians (Mooney and Kirshenbaum 11).

Plimer loudly proclaims his credibility, but is quiet when it comes to his credentials: his real professional expertise (a geologist, not a climate scientist), and his industry and political affiliations. Plimer is closely linked to political groups working actively to stop or at least delay action on climate change. He is listed as an associate of the Institute of Public Affairs, a Melbourne-based conservative think tank (Institute of Public Affairs); an allied expert for the Natural Resources Stewardship Project in 2007, a Canadian advocacy group that opposes the Kyoto Protocol (DeSmog Blog); ${ }^{4}$ and he is a member of the academic advisory council for Nigel Lawson's global warming skeptic group (Global Warming Policy Foundation).

Plimer has made a living out of the mining industry. He still is Professor of Mining Geology at the University of Adelaide, as well as currently director of three mining companies, and making a considerable income out of these directorships (Burton). Plimer also claims that his mining connections don't affect his views on climate change, and has argued that the introduction of a cap-and trade system in Australia would impact on the mining industry and "probably destroy it totally" ("lan Plimer Joins Lateline Business"). This extensive link to fossil fuel networks is not generally disclosed by the media outlets that cover Plimer's opinions.

Plimer has turned into a celebrity climate change sceptic; a rebel and a maverick, who speaks for "the average punter out there" (456). The oft-repeated statement about Plimer in the media is that he is "one of the few scientists" who disagree with anthropogenic climate change (see for example "lan Plimer Joins Lateline Business"). This characterisation of Plimer and his role in the debate, fits smoothly into the logic of the media. Plimer suits the media, and the media suit Plimer. How does this work in detail?

4 During the writing period of this article, the website of the Natural Resources Stewardship Project was not active. 


\section{The logic of the media and constructing the story of climate change}

The mainstream media are part of the wider field of cultural production, and the production practices within the media industries are ruled by certain logics. Among the logics of global media are storytelling, networking, noise, and the spectacle. The media uptake of Plimer is a product of the conditions of media production within environmental news reporting. There is a lot of work on the many constraints of news production-posed by factors of journalistic production such as news media norms, formats, and professional practices (in turn determined by commercial pressures) and how they influence the coverage of environmental issues (for example Anderson Media, Culture, and Environment and "Environmental Activism"; Boyce and Lewis; Wilson).

The daily deadlines of journalism, for example, make the coverage of scientific data over time difficult. This influences the practice of source-media relationships. Time, space, and scientific literacy pressures often lead to one-source stories, and the over-reliance on one source, usually an "expert". When it comes to who the groups and individuals are who are seen as credible and legitimate environmental news sources, the media are vulnerable to picking agents that have developed a strategy on how to gain access to the media as potential sources. The selection of sources is ideological and hierarchical, and groups with vested interests develop media strategies around that.

Media principles such as balance, which still define good practice within news production, lead to formulae of presenting two opposing points in dramatic form. This inhibits coverage of scientific complexity and skews the balance; what is in reality a tiny minority begins to look like a valid counter balance (Boykoff and Boykoff). In the case of reporting climate change, many scientists criticise the media for perpetuating indecision by including both scientific and non-scientific claims as if they were of equal validity (see for example Veron). Bjorn Lomborg (another celebrity denier, of The Skeptical Environmentalist fame) and lan Plimer are just two examples of the media making use of mavericks and outsider voices, and staging a struggle between scientists where there is consensus.

lan Plimer and his particular version of climate change denial has all the makings of a good story. He makes climate change a simple story. He is David fighting the Goliath that is the IPCC. There is a huge conspiracy by elite scientists against the average person. And, ultimately, there is nothing to worry about. This simplifying set 
of narrative sells better than climate change considered as a dangerous risk, and requiring massive changes in our energy systems and lifestyles. Simplifying the story in this way also is a powerful strategy, used skilfully by Plimer: climate sceptic arguments are attractive, because they offer an escape route from the fact that things will have to change.

Recurring story structures (such as conflict) are a main logic in the media, and Plimer provides media fodder by drawing extensively on popular culture in Heaven and Earth. Conspiracy theories and echoes of Dan Brown and Michael Crichton (whose State of Fear similarly turns global warming into a hoax by environmental groups to protect their business, and similarly gives this story a veneer of research by bolstering it with thousands of footnotes) feature extensively in the book. With this kind of storytelling, Plimer provides his version of what Ulrich Beck has described as the staging of environmental risk (2009). Simplified stories touch "cultural nerve fibres", provide and utilise "cultural symbols" (Beck 98) and, therefore, are powerful forces within public debate and for audiences.

Another reason Plimer appeals to the media is because of the logic of the spectacle. In his media appearances and publications, lan Plimer is sure and aggressive. With his authoritative, polemic, and polarising style, he has turned himself into a spectacle within the climate change debate. Among the main logic of the spectacle is the accumulation of spectacles (Debord). In a sense, the quality of what Plimer does and says in his media appearances and book doesn't matter, as long as he and his messages continue to be represented. Being given media space in itself already gives a certain degree of credibility, particularly for people with no specific knowledge on a particular issue. When individuals are cited with an affiliation to a well-known institution and a title, as in the case of "lan Plimer, Professor of Mining Geology at Adelaide University", there is automatic credibility. This is particularly the case when audiences are not familiar with the people involved, and when there is not usually time to look deeper into their backgrounds.

The best example of just how much the Plimer incident works within the logic of the spectacle is the Monbiot vs Plimer debate. After Plimer's claim that climate change is a hoax was recycled enthusiastically in the British magazine the Spectator in July 2009, George Monbiot, well-known for his environmental commentary for the Guardian newspaper, severely criticised both author and book for many mistakes that had already been pointed out in numerous book reviews by scientists (see for example Ashley; Lambeck). Plimer then challenged Monbiot to a public debate, 
hosted by the Spectator, Monbiot agreed on the condition that Plimer first answers a few questions about the sources for his claims, which Plimer replied to by accusing Monbiot of scientific illiteracy. The whole incident resulted in a considerable amount of media attention (interviews, blog entries, etc.) for both Monbiot and Plimer. Eventually, Plimer pulled out and the Spectator cancelled the debate. Finally, the Australian Broadcasting Corporation's program Lateline hosted a debate between Plimer and Monbiot on 15 December 2009.

This all is an example of how the media construct debate: as a staged debate, a fight between two opposing people and opinions, a duel in which its surrounding spectacle and the fact that it is happening counts for more than the content or the quality of the debate. The Plimer vs Monbiot interaction perpetuates the logic of the spectacle.

The debate took place live on ABC's Lateline, presented by Tony Jones. It began with a discussion of Copenhagen and the hacked emails of the Climatic Research Unit at the University of East Anglia. Over the course of the program, almost 25 minutes, the debate turned into a squabble rather than a debate. Plimer accused Monbiot repeatedly of bad manners, and Monbiot insisted that "Plimer just will not answer the questions". Since Plimer and Monbiot finally met for this debate after a long and public communication over the points of contention, this debate potentially offered a lot of opportunity for serious discussion, especially since there was almost half an hour of air time available. However, the time was mostly wasted.

There was nothing new in the debate to qualify the situation or supplement the media exchange that had already happened. Both Plimer and Monbiot repeated their messages: Plimer that people try to silence him and that climate change is about that "governments just cannot resist the opportunity to tax us more"; Monbiot kept on insisting that Plimer answer his original questions about the sources for his claims in Heaven and Earth. Monbiot's repeated "Answer the question, Professor Plimer" made him look tedious. Monbiot used the debate to reiterate the point that Plimer evades questions. But anybody who followed the exchange between Plimer and Monbiot already knew that, and didn't need to have that point repeated for 30 minutes. Plimer meanwhile used the debate as a PR opportunity and kept waving a copy of his book into the camera. He also successfully diverted the debate to a discussion of the East Anglia emails and the errors found in the fourth IPCC report in November 2009, rather than a discussion of himself and the quality of his claims. This pushed both Monbiot and Jones into having to defend the science community and spend time on explaining how these incidents do not mean what Plimer claims 
they mean. Both Plimer and Monbiot performed the stances they had already taken, and for the viewer there was in the end no new piece of information in the affair that would help to make a decision on who to trust and what to believe.

There would have been, for example, the opportunity to clear the question of the credibility of experts used by the media. Plimer repeatedly made the strong accusation that both Tony Jones and George Monbiot are journalists with no scientific credentials and expertise. Plimer focused on the crucial point of legitimacy, raising the question of who legitimates certain participants and discourses in the debate. This is crucial for the processes that create the credibility of participants in climate change debates. The media play a considerable role in this, and one would have thought that Jones and Monbiot, both experienced and respected journalists, would have jumped at this opportunity. But neither journalist managed to turn this into an opportunity to press Plimer on his credentials. Neither pointed out Plimer did not have any expertise or scientific credentials in the fields he is speaking out on, and purporting to be an expert in. Plimer claimed, for example, that "Climate science lacks scientific discipline" (15), and offered his Heaven and Earth as scientific work:

An understanding of climate requires an amalgamation of astronomy, solar physics, geology, geochronology, geochemistry, sedimentology, tectonics, palaeontology, palaeoecology, glaciology, climatology, meteorology, oceanography, ecology, archaeology and history. This is what is attempted in this book. (15)

Plimer does not have scientific training in all of these fields. Monbiot said in the debate that the role of the journalist is to keep pressing people to answer the questions they do not want to answer. But neither he nor Jones managed to ask pressing questions of Plimer that would clear for the audience who Plimer is, and how to evaluate his role in the debate.

Instead, the debate remained stuck in the formulae of conflict and duel; there is accusation and counter-accusation, petty nitpicking rather than quality arguments being made, and two people becoming increasingly agitated and angry. There were two people on two opposing sides, on stage together for their duel. At the end, it is not clear who is left standing, and who was right or wrong. It just stopped because the program ran out of time. The message of this staged debate (the episode was titled "Monbiot, Plimer cross swords") was that there are people with opposing views. This polarises the debate and helps to reinforce confusion and uncertainty. 
The following day the Guardian published a write-up of this debate by Monbiot: "So at last we've had our fight", Monbiot begins ("Showdown With Plimer"). Monbiot claims that he won the "battle" and "showdown" with Plimer. The fact that a highquality journalist such as George Monbiot was dragged into this logic demonstrates just how limited the media are by their own logics and conditions of production. The debate between Monbiot and Plimer showed that the reason why there is such a disproportionate level of confusing and confused climate change coverage, erring on the side of climate change denial in the face of a scientific consensus, cannot merely be attributed to the abuse of the media's responsibility as fourth estate; it also has to be explained by the logic of the mainstream media itself. The logics and conditions of production currently ruling the media produce the kind of coverage that perpetuates indecision and uncertainty, misrepresents facts, as well as under-informs on the political and historical and scientific contexts. This currently determines the quality of the public debate on climate change.

The Plimer vs Monbiot incident poses questions as to the responsibility of the media, and of the social function of journalism and news as one of the prevalent forms of mass media that communicate regarding the environment. If providing the sites and tools for a high quality debate on climate change is part of the media's role, giving a prominent voice to climate change denial as part of its construction of debate-or, rather, staging of debate-is problematic. It is particularly problematic if this kind of media coverage feeds off, rather than reports on, climate change denial, and fails to provide the historical and ideological contexts of that debate.

\section{The political dynamic of the climate change debate}

Since 2009, the media have been full of reports on the rise of climate change scepticism supposedly as a backlash following the 2009 UN Summit in Copenhagen, as well as the East Anglia emails in November 2009 and the criticism of the IPCC over the use of information that had not been rigorously checked.

With the circulation of this fashionable version of the climate change story, the media fail to convey that this rise in climate change denial has a history. Already in 1996, Paul Ehrlich (author of the seminal The Population Bomb) described efforts made to "minimise the seriousness of environmental problems" and to "fuel a backlash against 'green' policies" (Ehrlich and Ehrlich 1). Ehrlich points to the role of the media in this backlash (he called it "brownlash"): 
With strong and appealing messages, they [a diverse group of individuals and organizations with differing motives and backgrounds] have successfully sowed seeds of doubt among journalists, policy makers, and the public at large about the reality and importance of such phenomena as overpopulation, global climate change, ozone depletion, and losses of biodiversity. (Ehrlich and Ehrlich 1)

The media spectacles over deniers such as Lomborg and Plimer remind us that there is a strong anti-green current. Contemporary manifestations of eco-bashing continue this tradition from at least the 1990s onwards, in which environmentalism has been constructed as a political threat, and environmentalists as the new socialists. The Rio Earth Summit in 1992 can be seen as a "watershed for international environmentalism, but also as the beginning of the conservative backlash against climate science" (Hamilton "Nature will deal with sceptics"; see also Lindahl Elliot 226).

The historical background of today's climate change debate is characterised by battles between warnings from climate scientists, and attempts by fossil-fuel companies to protect their commercial interests (Hamilton Scorcher 16). Conservative forces are fighting the social and cultural transformation required to deal with climate change, defending the political and economic status quo, and holding on to such ideologies as the power of technology and science, progress, or mastery over nature. Climate change denial is part of this green backlash: an orchestrated campaign financed largely by coal and oil industries, with a long and successful history. After several decades of consolidating evidence for anthropogenic climate change there still is political inaction (Baxter; Hoggan and Littlemore; Oreskes and Conway).

What is the role of the media in all of this? The media campaigns of climate change deniers have been highly successful (Hoggan and Littlemore). In the first half of this essay I have argued that this is partly because the logic of the media offers many opportunities for the strategies of climate change deniers. The two media logics whose workings are part and parcel of the history and success of climate change denial are the logic of noise and the logic of networks.

The relations between lan Plimer and the media exemplify this. In his earlier battle with creation science, Plimer ended up in court because of his aggression in the campaign, and fellow scientists distanced themselves from Plimer (Lippard). What has been fascinating to observe in the case of lan Plimer is how quickly 
commentators leapt on Plimer and his Heaven and Earth, and whole-heartedly repeated its assertions. Commentators amplify voices, and as such amplifiers they play an important and potentially powerful role in public debate. In this context it needs to be noted that the people seizing on Plimer and his book were mostly media commentators who are connected to industry money and the climate denial camp. In Australia, the media figures who have reinforced lan Plimer's climate denial message were mostly the conservative Murdoch and Fairfax columnists. Their initial coverage of the book's publication provided free publicity and was promotion rather than news coverage (on the media coverage of Plimer and his book in Australia see McKewon).

Andrew Bolt (radio commentator and newspaper columnist), Christopher Pearson (The Australian columnist), and Miranda Devine (Sydney Morning Herald columnist) to name a few, all celebrated Plimer's book. Miranda Devine, for example, called the book a "comprehensive scientific refutation of the beliefs underpinning the idea of human-caused climate change". And here is Christopher Pearson's judgment of the importance of the book:

I expect that when the history of global warming as a mass delusion comes to be written, Australia's leading geologist will be recognised as a member of the international sceptical pantheon. As far as the progress of what passes for national debate is concerned, in all likelihood 2009 will be seen as the turning point and divided into the pre and post-Plimer eras.

Bolt, Pearson, and Devine are well-known right-wing commentators in Australia. In his book on climate change politics in Australia, Guy Pearse discusses the role and close connections of the media conservatives within the political scene of greenhouse policy (Pearse, particularly pp. 159-162; 247-250). Chris Mitchell, for example, editor of the Australian (where most of the media support for Plimer came from), seems to be immune to Rupert Murdoch's conversion to climate change. He has also won the 2008 APPEA JN Pierce Award (from the Australian Petroleum Production \& Exploration Association) for Media Excellence for coverage of climate change policy. The Australian Petroleum Production \& Exploration Association Ltd (APPEA) is the peak national body representing the oil and gas industry. The statement of the purpose of this award only thinly disguises APPEA's well executed PR strategy:

The J N Pierce award recognises excellence in journalism with respect to the upstream petroleum industry. [...] The selection criteria include 
excellence of writing style, accuracy of research, ethics, newsworthiness, flair and creativity, and public benefit. (JN Pierce Award for Media Excellence)

In Australia, this group of media figures is one of the voices telling the public that climate change is a green religion that lacks a scientific basis, and its amplification of the climate scepticism message has been a cycle of reinforcement:

Because most are employed to write in a manner that invites debate, a black-and-white depiction is far better than a balanced account. Having decided which side of the greenhouse debate they are on, they are in the perfect position to deliver the messages of denial and delay. (Pearse 160)

Many of these media sceptics are regular speakers at conferences and fundraising events for organisations funded by the big polluters. Andrew Bolt, Christopher Pearson, Alan Jones, Miranda Devine, and Michael Duffy, for example, have all given speeches at the Institute for Public Affairs (IPA), the Centre for Independent Studies (CIS), and the Lavoisier Group (Pearse 211); all think tanks that are vociferous on climate change policy. There is a deliberate membership overlap, but the links between these media figures, groups, and interests are not mentioned. The same is the case for the small group of "experts" this group of conservative commentators relies on as sources, both locally and internationally. Among them are Ian Plimer, Fred Singer, and Bjorn Lomborg; and, "virtually every source cited involves only a few degrees of separation from polluter cash" (Pearse 250).

Numerous reviewers have made the point that Plimer's book is not a work of science but, as Kurt Lambeck, president of the Australian Academy of Science, has put it, "an opinion by an author who happens to be a scientist" (Lambeck). This point, however, often is lost in the media covering Plimer's opinions. The logic of noise needs much more attention in our analysis of the media, particularly given the increasing trend in the media to give voice to commentary and political opinion.

In this context, looking at the quality of the climate change debate, as it is largely facilitated and mediated by the media, can teach us a lot about the media. There is criticism of news media generally that they are failing their social role and responsibility (as fourth estate, for example). But in the case of climate change, there is a particular case being made of the failure of the media. In the context of the political dynamic currently at work in the climate change debate-political inaction in 
the face of urgency; denial in the face of evidence-the question whether news reporting of climate change might be part of the reason for the green backlash has to be considered.

Do the mediations of the debate in the media provoke confusion about climate change, about what is fact and fiction, and hence delay the search for (technological) solutions, policy development, and social and political action? Social researchers repeatedly make the point that confusion causes disengagement from politics and the political process. This seems to be about to happen in the climate change debate. Climate change is going to be the defining problem of humanity. It has the potential to endanger, if not erase, human civilization. As such it is a textbook example of the need for knowledge and information in order to know how to act politically. The media-and particularly the news media-have been traditionally seen as central to the right to know in order to participate.

The media provide one of the most prevalent interfaces between scientists, policy makers, and members of the general public. Therefore, we need media that can help us ask the obvious questions: are the climate change deniers qualified; are they doing research in the climate change field; are they accepting money from the fossil fuel industry (Hoggan and Littlemore 4)? The media need to take more seriously the processes of authorising they perform for the public. Taking a closer look at the "credibility" of the "experts" relied on by the climate change denial campaign and amplified by the media reveals that most, like Plimer, have tangential qualifications and links to polluters and polluter-funded front groups. A closer look, minus the noise of the media, also reveals that they actually are a small number of people.

We also need to think through the logics of the media in the context of making sense of science and its role in society. The public understanding of science is limited. There is an increasing "politicisation of scientific research" (Hamilton Scorcher 13). This is why popular science books by scientists, such as by Plimer, matter. Rather than fostering confusion about science, or perpetuating the myth that the everyday person cannot understand science, the media could help to increase science literacy. A recognition of the limitations in media expertise (the news media, for example, have to give an account of other fields of expertise, such as climate science, but can only really give an account of itself as a field), and the different logics at work (science seeks consensus; media seeks conflict), would also help to think through and re-think the role of the media in public debate over climate change. 
And, finally, we need media that participate in discussions about the relationship between debate and social change. What kind of information, communication, and images can we use to shape perception and opinion and inspire action? In the context of environmental issues, such as climate change, Ulrich Beck has described the core of the relationship between media and politics: we have to rely on the symbolic politics of the media. The symbols that translate for us the many environmental risks are being produced in the battle over the meaning of these risks. The key question therefore is:

Who discovers (or invents), and how, symbols that disclose the structural character of the problems while at the same time fostering the ability to act? (Beck 98)

Caught up in the political dynamics of the debate, the media miss the purpose and the politics of the climate change debate: that the function of the debate is to prevent climate change (Beck). Part of the responsibility of the news media is to introduce new knowledge to the public. A book on the social construction of climate change asks the crucial question:

How is new knowledge introduced to the public? What roles do scientists, the media, leaders at all levels, interest groups and NGOs play in constructing knowledge for the public? (Pettenger 244)

This is part of the social role and responsibility of the media, alongside its logic of spectacle for entertainment and business purposes.

Why worry about the current quality of the climate change debate? Because undermining and misinterpreting environmental data prolongs an already difficult search for solutions (Ehrlich and Ehrlich). As is said so often now, to change our attitudes and to act in the face of climate change needs nothing short of a revolution (Lindahl Elliot 233). Plimer and his recycling of climate change denial messages and the re-recycling through the media represents conservative resistance to the transformations necessary in the face of global climate change; it merely is clinging onto the ideologies of mastery over nature and (economic) progress. Faced with the task of dealing with change, defending conservative values with no new vision will not create a public debate that can be of public benefit. A media consultant recently suggested that in the era of ecological challenges, we might need a "public-benefit journalism" (Cass), a journalism that benefits the public in the long run, not only particular groups with vested and short term interests. 
Angi Buettner is a lecturer in Media Studies at Victoria University of Wellington, Aotearoa New Zealand. Her most recent book is Understanding Media Studies (2010), with Tony Schirato, Thierry Jutel, and Geoff Stahl. She is currently completing Holocaust Images and Picturing Catastrophe: The Cultural Politics of Seeing, contracted by Ashgate.

\section{Acknowledgments}

Many thanks for the time gained by the help of my research assistant, Misha Jemsek. Many thanks also to Tony Schirato, for discussions about the field of the media.

\section{Reference List}

"About APPEA." APPEA, n.d. Web. 18 April 2010.

Anderson, Alison. Media, Culture, and the Environment. New Brunswick: Rutgers UP, 1997. Print.

---. "Environmental Activism and News Media." News, Public Relations and Power.

Ed. Simon Cottle. London: Sage, 2003. 117-132. Print.

Ashley, Michael. "No Science in Plimer's Primer." The Australian 9 May 2009. Web. 15 April 2010.

“Australian Museum Eureka Prizes." Australian Museum, n.d. Web. 19 April 2010.

Baxter, Cindy. Dealing in Doubt: The Climate Denial Industry and Climate Science: $A$ Brief History of Attacks on Climate Science, Climate Scientists and the IPCC. Amsterdam: Greenpeace International, 2010. Report.

Beck, Ulrich. World at Risk. Cambridge: Polity, 2009. Print.

Boyce, Tammy, and Justin Lewis, eds. Climate Change and the Media. New York: Peter Lang, 2009. Print.

Boykoff, Maxwell T., and Jules M. Boykoff. "Balance as Bias: Global Warming and the US Prestige Press." Global Environmental Change 14 (2004): 125-136. Print.

Burton, Bob. "Ian Plimer's Mining Connections." PRWatch.org. Center for Media and Democracy. 12 Nov. 2009. Web. 18 April 2010. 
Cass, Dan. "On the Slow Death of PoliticalTV: Time for Ecocene TV." Crikey 2 Sep. 2009. Web. 2 Sep. 2009.

Chrichton, Michael. State of Fear. New York: Avon Books, 2004. Print.

Debord, Guy. The Society of the Spectacle. New York: Zone Books, 1994. Print.

DeSmog Blog. lan Plimer_Plimer and the NRSP. Web. 17 April 2010.

Devine, Miranda. "Planet Doomsayers Need a Cold Shower." Sydney Morning Herald 18 April 2009. Web. 17 April 2010.

Dickinson, Janis L. "The People Paradox: Self-esteem Striving, Immortality Ideologies, and Human Response to Climate Change." Ecology and Society 14.1 (2009): n. pag.Web. 9 Nov. 2009.

Dodd, Adam. "Plimer's Heaven and Earth: A Conservative Coup?." Crikey 20 April 2009. Web. 25 Aug. 2009.

Doherty, Peter. "Climate Change and Cultural Change: The Challenge for the Future." Melbourne Festival of Ideas: Climate Change-Cultural Change. Melbourne University. 15-20 June 2009. Keynote address.

Ehrlich, Paul. The Population Bomb. New York: Ballantine Books, 1971. Print.

Ehrlich, Paul, and Anne Ehrlich. Betrayal of Science and Reason: How AntiEnvironmental Rhetoric Threatens Our Future. Washington, DC: Island Press, 1996. Print.

Enting, lan G. "lan Plimer's 'Heaven and Earth'-Checking the Claims." ARC Centre for Excellence for Mathematics and Statistics of Complex Systems. The University of Melbourne. Version 2.125 Jan. 2010. Web. 15 April 2010.

Ferguson, Sarah. "Malcom and the Malcontents." Four Corners. 9 Nov. 2009. Web. 19 April 2009.

"Global Warming Deal Unlikely This Year." Guardian Weekly 5 Feb. 2010: 6. Print.

Global Warming Policy Foundation. Academic Advisory Council. Web. 17 April 2010. Hamilton, Clive. "The Social Psychology of Climate Change." National Academies Forum: Climate and Culture in Australia. 27 Sep. 2002. Conference paper.

---. Scorcher: The Dirty Politics of Climate Change. Melbourne: Black Inc. Agenda, 2007. Print. 
---. "Nature Will Deal With Sceptics." Crikey 11 May 2009. Web. 25 Aug. 2009.

Hoggan, James, and Richard Littlemore. Climate Cover-Up: The Crusade to Deny Global Warming. Vancouver: Greystone Books, 2009. Print.

“lan Plimer Joins Lateline Business." Lateline Business. ABC News. 11 Nov. 2008. Web. 10 April 2010.

Institute of Public Affairs. People and Associates_lan Plimer. Web. 17 April 2010.

“JN Pierce Award for Media Excellence." APPEA, n.d. Web. 18 April 2010.

Karoly, David. "Heaven + Earth - Review." Science Show. ABC Radio National 13 June 2009. Transcript. Web. 4 September 2009.

Lambeck, Kurt. "Comments on Heaven and Earth: Global Warming: The Missing Science." Ockham's Razor. ABC Radio National. 7 June 2009. Web. 4 Sept. 2009.

Lindahl Elliot, Nils. Mediating Nature. London: Routledge, 2006. Print.

Lippard, Jim. "How Not To Argue With Creationists." Creation/Evolution 11. 2 (1991): 9-21. Print.

Lateline. About. ABC. Web. 18 April 2010.

Lomborg, Bjorn. The Skeptical Environmentalist: Measuring the Real State of the World. Cambridge: Cambridge UP, 2001. Print.

Manne, Robert. "Cheerleading for Zealotry Not in the Public Interest." The Australian 25 April 2009. Web. 17 April 2010.

Marshall, George. "Denial and the Psychology of Climate Apathy." The Ecologist Nov. 2001: n. pag. Print.

McKewon, Elaine. "Resurrecting the War-by-Media on Climate Science: lan Plimer's Heaven + Earth". JEA Conference "Journalism Education in the Digital Age", Perth, Australia, 30 Nov. - 2 Dec. 2009. Web. 24 June 2010. Conference Presentation.

Monbiot, George. “Showdown With Plimer.” Monbiot.com. Web. 15 April 2010.

---. "Spectator Recycles Climate Rubbish." Guardian.co.uk. George Monbiot's Blog. 9 July 2009. Web. 20 Aug. 2009.

Mooney, Chris and Kirshenbaum, Sheril. Unscientific America: How Scientific Illiteracy Threatens Our Future. New York: Basic Books, 2009. Print. 
Oreskes, Naomi, and Erik Conway. Merchants of Doubt: How a Handful of Scientists Obscured the Truth on Issues from Tobacco Smoke to Global Warming. Bloomsbury, 2010. Print.

Pearse, Guy. High and Dry: John Howard, Climate Change and the Selling of Australia's Future. Camberwell, Victoria: Viking, 2007. Print.

Pearson, Christopher. "Sceptic Spells Doom for Alarmists." The Australian 18 April 2009. Web. 17 April 2010.

Pettenger, Mary, ed. The Social Construction of Climate Change: Power, Knowledge, Norms, Discourses. Aldershot: Ashgate, 2007. Print.

Pew Research Center for the People and the Press. "Fewer Americans See Solid Evidence of Global Warming." Survey Reports. Pew Research Center. 22 Oct. 2009. Web. 17 April 2010.

Plimer, lan. Heaven and Earth: Global Warming, the Missing Science. Ballan, VIC: Connor Court, 2009. Print.

"Plimer, Monbiot Cross Swords Over Climate Change." Lateline. Australian Broadcasting Corporation. 15 Dec. 2009. Television.

Stern, Nicholas. The Economics of Climate Change: The Stern Review. Cambridge: Cambridge UP, 2007. Print.

Veron, J.E.N. A Reef in Time: The Great Barrier Reef from Beginning to End. Cambridge, Mass.: Harvard UP, 2008. Print.

Wilson, Kris M. "Communicating Climate Change Through the Media: Predictions, Politics and Perceptions of Risk. Environmental Risks and the Media. Eds. Stuart Allan et al. New York: Routledge, 2000. 201-217. Print.

World Bank. "Public Attitudes Toward Climate Change: Findings from a Multi-Country Poll." World Development Report 2010: Development and Climate Change. 3 Dec. 2009. Web. 18 April 2010.

WorldPublicOpinion.org. Environment: International Public Opinion on the Environment. Program on International Policy Attitudes. University of Maryland. Web. 18 April 2010. 